\title{
Seven Stories of Performativity and Advocacy: A Review of the Published Work of Stephen Town
}

\author{
Sheila Corrall \\ School of Information Sciences, University of Pittsburgh, Pittsburgh, Pennsylvania, USA
}

\begin{abstract}
Purpose. Stephen Town has been a thought leader and change agent in the academic library world for more than 20 years, who has produced a very large body of work in the areas of quality management and performance measurement that has been disseminated internationally. Town's retirement from full-time employment at the University of York provides a timely opportunity to review his contribution to the field.

Design/methodology/approach. The review outlines Town's career path and professional interests and then appraises his published output, concentrating on his contributions to thinking and practice in the areas of benchmarking, information literacy, service quality, and measuring the value and impact of academic libraries and information services. The discussion is organized thematically to illustrate the evolution and development of his interests and ideas over the review period and also references related work by other authors to set his work in context.

Findings. The study found many examples of innovative and creative work that had influenced thinking and practice in the library profession, including the development of models, frameworks, and tools with the potential to improve the effectiveness of service benchmarking, information literacy education, library advocacy, relationship management, staff evaluation, and impact measurement.

Research implications/limitations. The volume of published work necessitated some selectivity in the material covered, but the review provides sufficiently comprehensive coverage of the areas specified to represent the work effectively.

Originality/value. Town has produced a substantial number of publications as a practitionerresearcher that have not previously been reviewed independently as a coherent body of work. Keywords. Benchmarking, Information literacy, LibQUAL Library assessment, Performance measurement, Relationship management.

Paper type. Literature review/case study
\end{abstract}

\section{INTRODUCTION}

Stephen Town has been a thought leader and change agent in the academic library world for more than two decades. His professional work has been driven by a career-long commitment to service quality and performance improvement, which he has pursued in local workplaces, via national associations, and through global networks. His scholarly output amounts to over 50 publications for academic and professional audiences, including conference papers, journal articles, edited proceedings, guest editorials, book chapters, and a practical manual. His innovations and ideas have thus been disseminated widely and have exerted a seminal influence on professional thinking and practice both within the UK and around the world.

Town retired from his position as Director of Information at the University of York in Autumn 2015 and was awarded the degree of Doctor of Philosophy by publication in Summer 2016, making this an opportune moment to review his contribution to the library and information field. The review is arranged thematically by topic using a chronological logic to illustrate the intellectual development of Town's work, referencing other authors to contextualize key points. 
The volume of output precludes a comprehensive review, and material has been selected for its contribution to the chosen topics. After a brief outline of his career and interests, seven sections cover Benchmarking, Information Literacy, LibQUAL, Impact and Value, Value and Values, the Transcendent Library, and the Value Scorecard.

Town's professional career has been based in the academic sector with a management focus from the outset. After postgraduate library and information studies at Loughborough University of Technology, in 1978 he was appointed Medical Librarian at the Bryn Thomas Memorial Library of the Royal Berkshire Hospital in Reading, where he worked for six years. In 1984 he moved as Librarian to the Royal Military College of Science in Shrivenham (part of Cranfield University), where his role was successively expanded to include media and IT services as Director of Information Services (1993-2006) and Director of Knowledge Services (2006-2007), and also carried the title of Deputy University Librarian. In 2007, he moved to the University of York as Director of Library \& Archives, and became Director of Information in 2009, with additional responsibility for IT Services and the University's Information Strategy.

Town has been actively involved in the work of professional organizations, notably the Society of College, National and University Libraries (SCONUL) and its Advisory Committee (later Working Group) on Performance Improvement, which he chaired for a substantial period. He has served on the editorial boards of the journal, Performance Measurement and Metrics $(P M M)$, and the Northumbria International Conference on Performance Measurement in Library \& Information Services, and on the steering committee of its North American counterpart, the Library Assessment Conference. He has also served on committees and groups of the Library Association and its successor body, the Chartered Institute of Library and Information Professionals (CILIP), and been involved in national and international projects and programmes as advisor, consultant, and other roles. He has led units and modules on professional preparation and continuing education programmes for academic institutions, and advised Master's and Doctoral researchers.

Town's international reputation is largely based on his long and prominent involvement in the two major conferences associated with the specialist field of library assessment and performance measurement, where he has been a regular presence and contributor of papers over the entire lifespan of both events. His engagement with performance measurement can be traced back over the 20-year history of the Northumbria International Conferences (hereafter referred to as the Performance Measurement Conference), from his contribution on benchmarking at the first conference held at Longhirst Hall, Morpeth, in 1995, through to his case study of the use of people surveys to enact evidence based organizational change at the 11 th conference held in Edinburgh in 2015, where he also served as Conference Convenor (for the third time). Similarly, his association with the younger US-based Library Assessment event goes back to its inception in 2006, when he reported on the SCONUL Value and Impact Measurement Programme, and continued to his contribution to the 2014 conference on implementing the Value Scorecard that has been the focus of his work over the past five years. Town's contribution to the profession also includes seminal work on Information Literacy, and the interplay of the different strands of his intellectual activity is a key feature of his scholarship that justifies inclusion of material beyond the performance measurement arena.

\section{BENCHMARKING}

The background to Town's benchmarking work was the Total Quality Management (TQM) programme he initiated at the Library of the Royal Military College of Science in Summer 1993, at a time when a growing number of academic libraries and their parent institutions were exploring formal approaches to quality improvement. His 1995 presentation followed a similar 
pattern to many later contributions, setting activities at his own institution in the wider context of the management and (limited) library literature on the subject and using authoritative sources to explain and justify his approach. It is interesting to note Town's (1995, pp. 85, 86, 87) references here to the work of Parasuraman, Zeithaml and Berry, their methodology for assessing service quality, and "'Servqual' type walk-through assessment", which connects this early project with his later involvement in the LibQUAL+ community. Also notable is his characterization of the endeavour as "research into benchmarking as well as an attempt to benchmark" (Town, 1995, p. 86), establishing his position as a practitioner-researcher. His contribution to this first conference also signalled his stance on performance measurement (which was informed by quality management writers, including Oakland's (1993) classic work), as both critical of the inadequacy of existing measures and indicators used in libraries and concerned to move beyond cost and efficiency data to areas such as user experience, innovation, and staff development.

Benchmarking by definition requires a community of practice or interest and willing partners to make progress. In this case Town recruited a group of 20 academic library participants, again foreshadowing approaches he would use later to advance understanding and enhance practice simultaneously in his own institution and among his peers. The concluding remarks of his paper confirmed this intent, stating "the project was conceived partly as an experiment or research on behalf of the library community", and suggested formalizing the approach with "development of a UK Library Benchmarking Consortium" (Town, 1995, pp. 87, 88). The pioneering project was also presented at the 1995 Routes to Quality conference organized at Bournemouth University (Town, 1996), and within two years a set of seven benchmarking pilot projects had been formally launched with support from SCONUL and its Advisory Committee on Performance Indicators, with Town designated as coordinator. The projects covered advice (enquiry) desks, counter services, interlibrary loans, library/information skills, and the library environment (Martindale, 1997). Town (2000b, p. 159) defined two aims for the programme, "to give practical benchmarking experience to a wider number of HE practitioners" and "to produce a standard methodology for academic library benchmarking", confirming his determination to contribute to the profession at both practical and conceptual levels.

Town's leadership role in benchmarking is further evidenced by the selection of the RMCS library as a "demonstrator" project for benchmarking research funded by the British Library at Loughborough University, an invitation to revisit library experiences of benchmarking at the 1999 Performance Measurement Conference, his contribution on behalf of the library sector to a landmark volume on Benchmarking for Higher Education, and the publication by SCONUL of his benchmarking manual as a tangible output from the pilot projects (Town, 2000a; 2000b; 2000d). Looking back on this work after 15 years, we can find observations anticipating key themes of his later writing, such as references to "The failure of quantitative approaches...to illuminate the quality of a service" and a need "to address the more intangible, personal and subjective elements of providing a service" (Town, 2000b, p. 164). Town revisited benchmarking in another groundbreaking project (conducted with Frankie Wilson), which was presented at the 2005 Performance Measurement Conference in Durham and also published in PMM (Wilson and Town, 2006; 2007). The study explored whether benchmarking had real and lasting benefits for libraries and reached a tentative conclusion that effective use of the tool depends on a relatively mature quality management culture; another significant contribution of the study was the development of a Quality Maturity Model as a potential framework for measuring the quality maturity of a library service. 


\section{INFORMATION LITERACY}

Although national work on information skills development in secondary and higher education, can be traced back to the 1970s and 1980s, the period around the turn of the millennium was arguably the critical juncture for the UK information literacy movement. Town was a major player in this movement: his work was a seminal influence, not just on the performance measurement of information skills education in universities, as might be expected: Town provided the intellectual leadership for the conceptual development of the widely used Seven Pillars Model of Information Literacy (originally Information Skills), and was accordingly also a member of the expert group that produced the UK's "plain English" definition of information literacy in 2004 (Armstrong et al., 2005).

The skills agenda of the 1990s and 2000s provided Town with a unique opportunity to pursue his interests in performance measurement in relation to a strategic issue he later described as "one of the motivating factors in my entering the profession" (Town, 2000e, p. 11). Already a member of SCONUL's Advisory Committee on Performance Improvement, in December 1998 he became a member of the seven-strong Task Force on Information Skills established by the SCONUL Executive Board, ostensibly to "stimulate debate about the place of information skills within the context of current activity surrounding 'key skills', 'graduate-ness', and lifelong learning" (SCONUL, 1999, p. 2), but in reality to address specific, serious concerns about the conflation of information literacy and computer literacy in government statements on the subject, and general perceptions that the UK higher education community had fallen behind other countries in its thinking and practice in this area.

The resulting Position Paper, published by SCONUL in autumn 1999 (and later rebranded as a Briefing Paper), set out the seven "headline" information skills and associated diagram of the information literacy model as seven "pillars", supported by two building blocks, showing the desired progression by students from novice to expert information user. The thinking behind the model is not elaborated in the paper beyond reference to consideration of existing definitions of information skills. Though not the convenor of the task force, Town's role as a thought leader is evident in a subsequent conference paper, where he was personally tasked with elucidating the Seven Pillars Model for the practitioner community at a meeting organized by SCONUL at the University of Warwick in Summer 2000 (Town, 2000e). In characteristic style, before discussing the model, its attributes and its potential applications, he starts with the rationale and philosophy behind it, drawing on authoritative sources outside our field (in this case, the Book of Proverbs and the Oxford English Dictionary). He then advances a strong argument against prevailing notions of information skills education as a remedial or "welfare" activity, promoting an alternative view that

"[Information skills education] should be recognised as one of the key things that enables people, at universities and in their subsequent careers, to turn knowledge into wisdom through effective application" Town (2000e, p. 14).

Town (2000e) couples his argument for conceptualizing and positioning information skills education at a more advanced level with the rationale for developing a model specifically for the higher education context, where it needed to support the emerging agenda around graduate attributes contributing to employability, while also supporting the research activities of universities and being relevant to doctoral students and faculty. Another part of the rationale for the framework advanced here, which distinguished it from work of the Association of College and Research Libraries (ACRL, 2000) in the US, was its anticipation of the partnership service model now espoused by academic libraries for supporting both education and research. As Town (2000e, p. 14) explains: 
"We also wanted a model that could provide a framework for a comprehensive list of information-related skills, and that also could be used to demonstrate the full spectrum of learning activities involved in developing these skills, irrespective of the source of their development. That is, we wanted to place the library-provided elements within a framework that would encompass elements which might be provided by other parties, particularly academic staff and IT staff."

This upfront recognition of the collaborative dimensions of information literacy activities in higher education anticipated later models such as the blended librarian movement (Bell and Shank, 2004) and the potential role of research supervisors (i.e., faculty advisors) in information literacy (RIN, 2011).

Another distinctive feature of the model is the way it dealt with the problem of stakeholders equating information skills with information technology (IT) skills. Town (2000e, p. 16) explains how he "tried to build the model from a starting point of ignoring technology and solely thinking about users, libraries and the academic literature", on the basis that it should be immaterial whether the user approached the literature via a virtual library or a physical system. The Seven Pillars provided a neat solution here, by incorporating both "IT skills" and "basic library skills" in the model - but as related, foundational elements, separated from the components of information literacy represented in the seven headline skills or pillars. Placing basic library skills at the base of the model also differentiated information literacy education from the previous more limited activities of library instruction and user education.

Town's position in the information literacy movement was acknowledged in an invitation to author a chapter for a book on Challenge and Change in the Information Society, where he considers the role of information literacy in society. Here Town (2003b, p. 98) concluded his discussion with the prescient assertion that "Measurement will be key to the future of information literacy as a useful concept", arguing that defining the information literacy skills needed for an information society was only the starting point, and needed to be followed by clarifying what is important about the concept and about the education programmes designed to develop the key skills, which in turn required systems to measure the outcomes for individuals. Town was the natural choice to lead this action line for SCONUL with his dual involvement in its Information Literacy and Performance Improvement groups. The chapter outlines the work he initiated to develop a measurement framework for information literacy, using the Oakland (1993) Critical Success Factor methodology from his benchmarking projects to collect data from 30 groups of practitioners via 10 workshops at sites across the UK. He provided fuller accounts of this work as it progressed in the Spring 2001 SCONUL Newsletter, at the 2001 Performance Measurement Conference in Pittsburgh, and at the 2002 IT\&ILit conference held in Glasgow (Town, 2001; 2002b; 2003a). He concludes the Glasgow paper by reiterating the need for librarians to shift from their position of "relative isolation and independence to one of collaboration with teachers and others", on the basis that information literacy activity "is about education rather than mediation, or service or information provision" (Town, 2003a, p. 63).

\section{LibQUAL}

Town played a key role in bringing the ARL LibQUAL+ survey to Europe, championing its adoption by SCONUL members, promoting the benefits of implementation, and encouraging further take-up. His interest in the SERVQUAL model on which LibQUAL is based can be traced back to his early work on benchmarking for quality management (Town, 1995, p. 86) and a paper prepared for the 1997 Performance Measurement Conference, which was updated for publication in the launch issue of $P M M$ Town, 1998; 2000c), arguing here 
"current data collection methods and structures obscure, rather than illuminate, performance and provide a misleading picture of what performance is or should be" (Town, 2000c, p. 43).

He was particularly critical of evident reluctance in the UK academic library sector to move beyond "traditional counting", to consider qualitative data, encompass non-standard processes and project-based work, and particularly to include "the voice of the user". He then set out an ambitious agenda for reform, with measures related to the tenets of quality management (including SERVQUAL) at the top of his list, which also included impact, competence improvement, cultural analysis, value added, and other issues that resurfaced in later work.

Town negotiated UK involvement in LibQUAL at a time when the instrument was still in its pilot phase in the US. His brief report to members in 2003 describes how the 20 libraries in the SCONUL consortium were the first participants outside North America, representing around one-sixth of the UK's higher education student population, whose trial participation took the total number of library organizations participating in LibQUAL+ to 308 (Lock and Town, 2003). Town (2004b) provided a fuller account of the UK pilot at the 2003 Performance Measurement Conference in Durham, when he related LibQUAL+ to various UK "customer understanding" efforts initiated at institutional, professional, and national level as part of quality management and quality assurance programmes in the 1990s, including his own benchmarking work reported at the first Performance Measurement Conference (Town, 1995). Members reportedly liked the ability to benchmark results against peer institutions and compare their results against a national average, as well as the limited local effort required, indicating how benchmarking had by then become part of the academic library mindset.

Despite some modification of the instrument to "British English" and addition of "local questions" suggested by the UK LibQUAL+ Steering Group (Town, 2004b, pp. 213, 214), "Cultural differences in language and assumptions about the role of libraries inherent in the survey....were seen as drawbacks" (Lock and Town, 2003, p. 9), and SCONUL participants generally reported lower response rates for LibQUAL+ than for previous customer satisfaction surveys. However, Town (2004b, p. 217) used an institutional case study to compare his own library's LibQUAL+ results with a previous local survey and show that "The lower response rate with LibQUAL+ did not seem to affect its ability to discriminate similar user issues" (positive and negative). He concluded the instrument was satisfactory for the UK, but could be improved to get better response rates. A 2005 update in the SCONUL newsletter reported 43 UK and Irish libraries had taken up LibQUAL+, increasing representation to around one-third of the target population; benchmarking data and the "managed and serviced process" continued to be highly valued by participants, but by this time institutions were also reporting changes made on the back of LibQUAL+ results, including success in "lobbying for more funds to improve the environment, resources or PCs" (Lock and Town, 2005, p. 44). A similar report was given at the 2005 Performance Measurement Conference in Durham (Lock and Town, 2007b), where Lock and Town (2007a) also presented a fuller case study of LibQUAL use at the Shrivenham campus. Their study gives additional insights into the use of survey results to define and successfully implement a local service improvement programme, and shows how the LibQUAL+ instrument was "more discriminatory in setting the agenda for change" than the institution's exit survey (Lock and Town, 2007a, p. 225).

By the time of the 2011 Performance Measurement Conference in York and the 2012 update to SCONUL members, 72 UK and Irish libraries had used LibQUAL+, with over half using it more than once (typically every two years), and there were many more examples of results being used to secure additional funds; to improve resources, services and facilities; and even to inform public debate on developments in academic libraries (Killick and Town, 2012a; 2012b). The conference paper also compares the SCONUL results with equivalent scores for ARL libraries between 2004 and 2011, noting some interesting differences (Killick and Town, 2012b). 
In 2014, Town contributed a UK and Ireland perspective to an expert panel at the Library Assessment Conference in Seattle on lessons learned from LibQUAL+ use over its 15-year life (Kyrllidou et al., 2015), and then drew on material from the session to provide a case study of LibQUAL+ for an edited volume on Quality and the Academic Library with global coverage (Town, 2016). This chapter documents Town's own impressive involvement in LibQUAL+ at local, national, and international levels: in addition to leading LibQUAL+ implementations at his own institutions, translating the instrument from American to British English, and coordinating the SCONUL Consortium for more than 10 years, he served on the (US) Steering Committee, advised and supported the development of consortia in other countries, and assisted individual applications of the survey in Europe and beyond. In addition, the University of York was "the first in the UK to add the TechQUAL survey to annual LibQUAL+ surveys" (Town, 2015b, p. 247). His review of UK and Ireland usage reinforces the positive views of LibQUAL+ already noted, with one particularly striking outcome the "use of LibQUAL+ Library as Place scores and trends to advocate and obtain substantial capital resource for either new build or refurbished libraries" (Town, 2016, p. 213). His personal experience over seven years at the University of York also points to more subtle benefits of the tool in influencing cultural change, which he describes as "profound" on his campus:

"Accurate and reliable data has replaced anecdote, received wisdom and negative cultural web stories in the discourse within and between the library, its users and university management" (Town, 2016, p. 214).

Town also credits LibQUAL+ (used by 2,645 institutions in 31 countries and 21 languages on five continents at the time of writing) with "creating an open climate and culture of measurement and assessment across an international community", and encouraging benchmarking in a way that no competing products can match. As the pioneer who had the foresight to propose its first use in libraries beyond North America, and a longtime advocate of benchmarking as an approach to quality improvement, Town surely deserves some of the credit here himself. However, it is important to note that while Town (2016, p. 219) views LibQUAL+ as "an indispensible tool", his final critique characteristically also identifies areas where development of new or improved measures could be useful, notably in relation to distance learners and researchers for whom Library as a Place may be a less useful construct, and in relation to the digital library and electronic resource management.

\section{IMPACT AND VALUE}

In 2005, the SCONUL Working Group on Performance Improvement (WGPI) was tasked with responding to member requests for assistance in defining the contribution and proving the worth of their library services, which was reported as a "top concern" for university library directors (Town, 2007, p. 437). A work programme was awarded funding, with Town as Project Manager. The intent was to devise new instruments and/or techniques for measuring impact and value for money, and to develop "a full coherent framework" incorporating existing WGPI offerings, in line with its commitment "to provide a toolkit of data, measurement techniques and instruments which meet the needs of the membership" (Town, 2006, p. 114). The first phase of the Value and Impact Measurement Programme (VAMP) included an audit and critical review of existing products followed by a gap analysis to identify needs. Town's progress report to SCONUL members in Summer/Autumn 2006 highlights "value for money, staff measures, and process costing" as areas of weakness or under development, which then formed the basis of two sets of "content products" work packages for the second phase of VAMP (Town, 2006, pp. 115, 116).

Town's (2007, p. 440) fuller interim report on VAMP to the 2006 Library Assessment Conference in Charlottesville confirms staff measures as a key requirement identified in both the 
survey of SCONUL members and workshops at the SCONUL conference conducted in the first phase of work. This report identifies another important area for measurement development as "the integration of the library with the research enterprise of an institution", noting that national audit requirements in the UK focus on the integration of libraries into the teaching enterprise. However, while Town acknowledges SCONUL members have made significant progress in using LibQUAL+® data to evidence user satisfaction, he argues that there is still a gap to be filled here as such measures are in practice library centric and do not have the desired focus on educational outcomes or impact. Town (2007, p. 443) argues in this paper that the two terms "outcomes" and "impact" are interchangeable, equating impact with "higher order effects" of the library, but noting it may operate at multiple levels (personal, institutional, professional, vocational, societal, national, and international). Town (2007, p. 441) also criticizes "the view that satisfaction equates to impact" as too narrow:

"Students and staff may be satisfied with the experience of engaging with their academic library, but this is not evidence that it makes an educational difference in either the short or long term".

A notable exception here was SCONUL's work on information literacy (in which Town played a leading role), where the relationship between library activities and learning outcomes is potentially much easier than in other areas to define and measure and thereby demonstrate educational impact, and at multiple levels, as Town (2007, p. 441) observes:

"The connection between information literacy and learning clearly offers a good opportunity for direct impact measurement at the individual level, and also at the institutional level where information literacy attainment is embedded in university strategies."

Interestingly, particularly in the light of his later personal research in this area, Town reports an emerging view from the SCONUL conference workshops that "the precise cause and effect mechanisms of library activity on educational attainment, and in particular how library resources and services work in a pedagogic sense may be beyond the scope of the VAMP programme" and "there is a 'Big Project' here needing to be recognised and scoped, and that specifying this might be part of the VAMP exit strategy". He concludes this report by identifying methods for demonstrating library impact on student learning and research outcomes as "the most critical product for the VAMP project (Town, 2007, p. 444).

\section{VALUE AND VALUES}

Town's initial reports on VAMP promote a broad interpretation of value measurement, arguing a need to reach beyond "value for money" and measure "the real value added" by libraries and their staff (Town, 2007, p. 443). He pursued this argument at the 2008 Library Assessment Conference in Seattle, in both his invited response to the keynote panel and a follow-up report on VAMP (Town, 2009a; 2009b), and at a deeper, philosophical, level at the 2009 Performance Measurement Conference in Florence, in a presentation subtitled "A metaphysical enquiry" (Town, 2011a). In Seattle, his personal response on "The most important challenge for library assessment" started to make the important, but largely neglected, connection between "value" and "values" that was to form the basis of much of his subsequent work, and to argue the case for "a new type of scorecard... based on the implicit values or beliefs we hold as librarians". This was not an endorsement of the library-centric approaches he had previously criticized, but a call to broaden and elevate conceptions of assessment to reflect the interests, values, and aspirations of multiple stakeholder groups, but to move "beyond obvious and immediate pressing concerns" and not forget librarians in the process. Thus, "A key measure would be the degree to which our services play a part in the lifeflows and workflows of our users", but other 
measures would reflect core values from a librarian perspective, such as "Developing people" (Town, 2009b, p. 22).

Town (2009a, p. 388) uses his update on VAMP to reinforce his argument for libraries to "reflect a more transcendental perspective on both education and research" (anticipating another theme he would later develop and elaborate), and to reject prevailing "reductionist measurement systems... which do not adequately reflect the enduring values and value of our services". At a practical level, the main development reported here is the SCONUL Performance Portal, created as a key deliverable of VAMP, not only to facilitate access to assessment and measurement resources, but also "to build a community of practice in performance improvement in UK and Irish academic libraries". The portal is thus presented as "an experiment in social networking and Web 2.0 technologies", as well as a toolkit (Town, 2009a, p. 389). The Value area of the portal had not yet been populated, but was a priority for development, and Town (2009a, p. 390) uses the opportunity to launch a discussion on developing "meaningful measures of value" for academic libraries, commenting on the range of approaches used in the UK public sector, and using three case studies to illustrate the challenges of cost analysis and desirability of adopting standard methods to facilitate international comparisons and benchmarking. He again counsels against reductionism, and calls for higher level debate:

"In all this we should not forget that value theory is not about money, but about what is ultimately valuable in the sense of good or bad. Any framework we develop for 'value' should be based on our 'values,' and those of our parent institutions. In other words, we need some metaphysical assumptions about values on which to base our assessment of value, so that we avoid any absurd reductionism" (Town, 2009a, p. 390).

At the Florence conference, Town (2011a) built on a point made in his Seattle report (Town, 2009a) about the trend toward an instrumental style of research - evident for several decades, and therefore predating the current requirement from funding bodies for research with demonstrable impact - to warn that such instrumentalism and reductionism could damage the idea of libraries as services with a more holistic, higher purpose. After revisiting the approaches to value referenced in his Seattle paper, he reviewed value measurement in libraries, including an emergent interest in intangible assets (Kostagiolas and Asonitis, 2009; White, 2007). He then moved on to his "metaphysical enquiry" into value, based on definitions and perspectives on value offered by scholars from different disciplines, followed by a pragmatic case study of the University of York Library \& Archives Values initiative, which drew on frameworks and methods from management theory and business practice, and used a Web 2.0 tool as well as an awayday to get staff input, but also asked users (students and academics) what they valued. He concluded his Florence presentation by again suggesting the need to broaden our concept of value in the library context. Another later account of the York values investigation provided further support for this position:

"By asking what users value, instead of what they want, need or rate as satisfactory, we received answers which were surprisingly different from what we had learned through quality approaches" (Town, 2011b, p. 320).

\section{THE TRANSCENDENT LIBRARY}

Town's (2011c) keynote paper for the Value and Impact theme at the 2010 Library Assessment Conference in Baltimore can be viewed as the formal launch of his concept of "the transcendent library" and unveiling of his related proposal of a values-based scorecard as the big idea to help the profession rise to the challenge of proving the worth of libraries in contemporary society. The notion of (academic and research) libraries as "transcendental" or "transcendent" had been 
floated at the Seattle and Florence conferences (Town, 2009a; 2011a) as part of his critique of "the simple minded reductionism which often accompanies the quest for impact and value measurement" (Town, 2009a, p. 387). The concept is also promoted in his 2011 review of developments in library evaluation for a more generalist audience in Libraries and Society, where he discusses how "changing evaluation frameworks continually shape what libraries are and what they do" (Town, 2011b, p. 303) and warns readers:

"the transcendent, collective and connective role of libraries does not play well in an increasingly individualistic, disconnected and fragmented society"(Town, 2011b, pp. 303, 305).

In this book chapter, he reiterates the need for more holistic measurement systems to reflect the "transcendent contribution" that libraries make, and describes the development of information literacy in individuals as "a very good example of the creation of something transcendent which continues to deliver value well beyond the boundaries of the library or parent institution" (Town, 2011b, pp. 313, 314). An important dimension of Town's (2011a; 2011b) emergent model is its incorporation of intangible asset measurement based on the concepts and tools of intellectual capital reporting; which are firmly established in the field of management, but have been largely neglected by the library assessment and performance measurement community. Town (2011b) suggests that using such approaches to broaden the scope of assessment activities to take account of the human, structural, and relational capital generated in libraries may be particularly useful in evaluating important aspects of library performance that have been poorly represented in existing measurement and evaluation frameworks; for example, staff capability and capacity, services built around both real and virtual collections, and library relationships with stakeholders and society. He concludes this section by arguing that traditional tools provide only a partial answer; economic value tools may offer something new, but "not providing a transcendental answer of the kind sought"; and he makes the additional point that devising effective measures here will encourage behaviours to maximize such assets (Town, 2011b, p. 316).

However, the real breakthrough contribution of his proposed framework is the explicit link Town (2011a; 2011b) makes between value and values in the context of performance measurement, which was foreshadowed in his Florence paper (Town, 2011a). To advance this argument, he draws on value theorists from other disciplines, including Cameron et al.'s (2006) Competing values leadership, as well as insights offered by library scholars Pors and Johannsen (2003) into value-based management. The concluding section of his book chapter (subtitled "value, values and transcendence") captures his key message: "The framework for proof of value will arise from consideration of the values of organisations or societies, and will extend well beyond economic value contributions" (Town, 2011b, p. 321). The final version of his Baltimore keynote, which was published with minor edits in Library Quarterly (LQ), states this connection upfront, asserting that "...the right place to seek answers to value contribution will not be in immediate goals but in values, as concepts of value depend entirely on value systems"; and he then elaborates this point to round off the first substantive, context-setting section of the paper, arguing that "there is a need for a broader assessment of the meaning of value and recognition that value is dependent on value sets or systems" (Town, 2011d, pp. 111, 114).

The Baltimore/LQ paper revisits and elaborates previous arguments on the cross pressures on library managers, the meaning of value and its transcendent dimensions, developments in library evaluation, and deficiencies of existing frameworks. A definition of the transcendent library is provided here:

"one in which the value can be judged beyond the immediate and that contributes not only to institutional objectives or immediate bottom-lines alone but also to broader value systems within the institution, and beyond, to a higher-order beneficial contribution to individuals, 
groups, and societies" (Town, 2011c, pp. 269-270; Town, 2011d, p. 115).

The section on Value, Values and Valuation extends his prior discussion with a convincing critique of Michael Gorman's (2002) position on "The value and values of libraries", arguing that outright rejection of current values that conflict with traditional, timeless (and by definition transcendent) values is not a viable stance for the profession:

"We have to place our values measurement firmly in today's context, resolve conflicting values debates, and provide evidence of contribution to values achievement beyond mere espousal" (Town, 2011c, p. 272; Town, 2011d, p. 120).

A further argument for centering library assessment and performance measurement on values in place of existing bases is equally compelling, and elaborates the case made earlier for incorporating an intellectual capital perspective in evaluation frameworks:

"Thus a values based approach to measurement within libraries may be a better basis than traditional measurement systems which tend to treat both users and staff as blind actors in a rational process of exchange, and one which might therefore need to be squeezed to be as efficient as possible. A values perspective might suggest that these often messy interactions are also a source of real value creation, generating relational capital in the trust confidence and knowledge on which new forms of service can be built." (Town, 2011c, pp. 272-273; Town, 2011d, p. 120).

Moreover, in terms of relating library evaluation to the business of its parent institution, the proposed framework accordingly shifts and elevates the alignment focus from goals to values as Town (2011c, p. 273; 2011d, p. 121) explains, "The source for values measurement is not in institutional goals but, rather, in institutional value statements".

The concluding synthesis of the Baltimore/LQ paper then asks specifically how the concept of the transcendent library might assist the assessment of library value, and approaches the answer via three questions related to the value propositions of the transcendent library, the measurement of value added by the library, and the presentation of evidence as proof of value. Town emphasizes the need for a collective and holistic approach, which recognizes and resolves competing and shifting values, rises above and beyond immediate goals and narrow value sets, and reflects wider stakeholder concerns, broader common goods, and the intangible value created by the library within and beyond the institution. His key message here is about shifting the focus of assessment and measurement and lifting it to a higher, transcendent level; not by abandoning current tools, such as LibQUAL+ and the Balanced Scorecard, but rather by adopting a broader framework, with a "higher-level values scorecard" as its centerpiece.

The values scorecard is defined here only in general terms as "moving beyond...practical goals of efficiency, satisfaction, cost effectiveness, and staff capability to more transcendent goals, recognizing the library's broadest influence on, for example, education, research, knowledge assets, corporate health, innovation, inclusivity, internationalization, and partnerships" (Town, 2011b, p. 274; Town, 2011c, p. 123). But this is not just about new measurement systems; a corresponding shift in how we think about the whole concept of a library is also required - "we are not only an information delivery service but also a key nexus of knowledge-related activity within and beyond the institution". Here Town (2011b, p. 275; Town, 2011c, p. 123) echoes the arguments of other library change agents, such as David Lankes and Brian Mathews, about moving the information profession to a more proactive role "from being the source of knowledge to the facilitator of it" (Lankes, 2008, p. 14) on the basis that rather than being in the information business, or part of the service industry, libraries are "in the inspiration business" (Mathews, 2009 , p. 38) as "an indispensable part of knowledge generation" (Lankes et al., 2007, p. 32). He also anticipates growing recognition in the sector of the need for libraries to rethink their 
traditional "service-and-support" model and "soldier" orientation, and reposition as collaborators, campus leaders, and agents of progress and reform in the world of scholarly communication (Anderson, 2015; Posner, 2013).

Town (2011b, p. 275; 2011c, p. 123) reiterates here how the knowledge/intangible assets created by libraries must be central to the new or improved measures developed: "The assessment of intangible value added will be key to developing a compelling story around our overall value proposition". He advocates the established threefold approach to intangible asset evaluation based on structural, relational, and human capital, emphasizing the need for clearer recognition of the value added by both the internal collaborations and partnerships developed by libraries and "the many external relationships that libraries build for long-term benefit", and also highlighting the need to deal properly with the "neglected area" of the value added by the skills and capabilities of library staff, whose contribution in the more complex digital environment is often less appreciated than before (Town, 2011b, p. 275; 2011c, p. 124). He also suggests a mix of quantitative data and qualitative evidence - in narrative form - will be required to demonstrate library value, confirming Brophy's (2007, p. 157; 2008, p. 15) arguments that "narratives can be a powerful addition to the evidence base" of library managers and "the most usable tool to cope with complexity", such as the situation currently confronting us.

\section{THE VALUE(S) SCORECARD}

Town's (2011b; 2011c) novel idea of a values scorecard in effect defined his research agenda for the next five years, as he embarked on an ambitious programme of conceptual and empirical work to elaborate his proposed framework and put it into practice at the University of York. At the 2011 Performance Measurement Conference in York, he reported on work done to develop the scorecard framework, defining four basic dimensions, and the different elements and areas for assessment and measurement within each dimension. Town and his co-author Martha Kyrllidou of ARL drew on scenarios developed by ARL and SCONUL as well as statements from the University of York to contextualize and future-proof their work on the framework, which was published in the proceedings and in a special issue of PMM (Town \& Kyrillidou, 2012; 2013).

While scorecards were by then widely used in academic library assessment and in other sectors for intangible asset evaluation, Town's model breaks new ground in its selection of dimensions, specification of elements, combination of tangible and intangible asset measurement, and origination of a meta-assets category for intangible assets built to add value to physical assets. The choice of relational capital as his first dimension reflects an emerging consensus that our profession is essentially in the relationship business (Mathews, 2014), but Town subdivides this dimension to specify competitive position capital as a new measurement area acknowledging the potential benefit of a library's reputation beyond its institution. Another example of the nuanced thinking behind the framework is his fourth dimension, library momentum, which is concerned not just with innovation - another current preoccupation of the profession (German \& Namachchivaya, 2013; Jantz, 2012; Molaro \& White, 2015) - but its pace. His concluding remarks are interesting: anticipating the question of how this scorecard relates to the now familiar balanced scorecard promoted by associations such as ARL, he explains how it supplements and extends existing models, but also suggests that "a 'balanced' scorecard may not be what is sought" in particular local circumstances, which should determine the make up of the scorecard to reflect institutional values (Town \& Kyrillidou, 2012, p. 421; 2013, p. 15).

\section{Human capital}

At the 2012 Library Assessment Conference in Charlottesville, Town looked in detail at the human capital component of the intangible assets included in the library capital dimension of his scorecard in a paper co-authored with York colleagues (Town, Black, Hall \& Smith, 2013), which 
he revised and expanded in a later journal article that drew on newer research, publications, and real-world cases (Town, 2014b). His work here drew extensively on thinking and practice in human capital measurement beyond the library domain, and significantly extended prior work on staff evaluation in academic libraries - an area that seemed not have received due attention at conferences and in published work, despite its inclusion in widely used evaluation frameworks (such as the balanced scorecard and common quality assessment systems). His approach is distinctive in both the specific measures suggested and in offering a complete, coherent system, with four dimensions that together are considered "necessary and sufficient to measure the value of our people" - Capacity, Capability, Climate of Affect, and Culture of Momentum (Town et al., 2013, p. 56; Town, 2014b, p. 75).

A distinguishing feature of the model is the identification of related data needed to prove beneficial outcomes. Thus Capacity data, such as staff numbers and turnover, "needs to be combined with market data" to demonstrate fit with existing context; and Capability data "needs to be linked to strategy and strategic achievement to prove its worth" (Town et al., 2013, p. 5758; Town, 2014b, pp. 75-76). The Climate of Affect dimension is similarly elaborated to explore "the link between emotion and behaviour": while "staff empowerment and total involvement must both be strong for maximum efficiency of value creation" (Town et al., 2013, p. 57; Town, 2014b, p. 77), evidence such as data from ClimateQUAL+ "needs combining with other measures to prove real benefit" and "to justify the received wisdom that people with positive affect deliver more and better" (Town et al., 2013, p. 58; Town, 2014b, p. 77). Here Town suggests combining affect data with productivity or creativity data, and exploring potential links between ClimateQUAL+ and LibQUAL+ data. For Culture of Momentum, he proposes assessing the volume and speed of improvement projects in relation to competitors, but linking such measures to evidence of enhanced library or institutional reputation to demonstrate competitive impact; he also notes the library's quality capability as critical here, suggesting possible application of the Quality Maturity Model from his benchmarking work with Wilson as a "meta-level measurement" (Town et al., 2013, p. 57; Town, 2014b, p. 77; Town and Wilson, 2006; 2007).

The 2012 conference paper used evidence and insights from University of York staff surveys, follow-up meetings and ClimateQUAL participation to contextualize the proposed scorecard for human capital in contemporary library practice, but both papers close by highlighting further work needed to correlate people data with library outcomes and transcendent contribution (Town et al., 2013; Town, 2014). Town (2015a) followed up his 2014 article with a fuller longitudinal case study of the use of people surveys at the University of York Library and Archives over seven years. In relation to the values scorecard, the focus is largely on the Climate of Affect dimension, investigating the "lived experience" of staff and the effect of the culture of the library and "engagement" of its staff on delivery of service improvements. While Town does not claim evidence of causation here, or even a clear correlation between staff affect and service excellence, the study does show that a serious commitment to assessment and evidence-based interventions related to structure and culture can improve survey results. He identifies a "key learning point...that cultural stories are often in conflict with objective scores or reality" and suggests "narrative replacement" as a multi-level management strategy "to reinforce improvements and shift the culture to more positive expressions" Town (2015a, p. 641).

\section{Relational capital}

Town (2014a) used the 2013 Performance Measurement Conference in York to develop his ideas on the relational capital dimension of the value scorecard in a paper presented as a companion piece to his explorations of the human dimension (Town et al., 2013; Town 2014b). which was also published in a special conference issue of Library Management (Town, 2015d). Here again he draws on business and management theory (specifically, transaction cost theory and relationship marketing concepts), but also links his discussion with prior work in the library 
field on assessing academic liaison and customer relationship management, and the contributions of Niels Pors (2008) on the relationship between social capital, operationalized as trust, and library effectiveness. Adapting a "six markets" model from relationship marketing, replacing "influence" and "referral" markets with "governance" and "reputation" markets, Town (2014a, p. 331; 2015d, p. 243) presents a "seven markets model" for academic libraries as a framework for identifying "the complete web of relationships in which a research library might be engaged and which require maintenance" - and assessment. He then articulates three areas for relationship measurement, each with two " $\mathrm{C}$ " components, again drawing on a model from the business world: consciousness and congruence (assessing awareness and fit), communities and communication (assessing strength and processes), and causality and comeback (assessing outcomes and returns).

\section{Practical application}

The final paper in this series (Town, 2015b) is based on and expands on presentations at the 2014 Library Assessment Conference in Seattle (Town, 2015c) and at a two-day conference at the Library and Information Studies Centre at the University of Cape Town. In addition to providing proof of concept by reporting a real-world implementation of the value(s) scorecard at the University of York, Town (2015b) reflects on the contribution of his framework to understanding and practice in the field, including its relationship to the balanced scorecard. Having used both singular and plural in the title, he confirms "value scorecard" here as the simpler and better descriptor, given its aim "to prove library value", although "Values remain...at the centre of both the diagram and the concept" (Town, 2015b, p. 235). In setting the context for the study, Town $(2015 b$, pp. 237, 238) argues for "infrastructure, innovation and partnership engagement to feature more strongly in library measurement frameworks in future", along with "impact proof", and thus justifies the four dimensions of his scorecard. His case study takes each dimension in turn, discussing the meaning of its constituent elements and providing examples of the data collected to support proof of worth.

A key contribution of this study is its further articulation of the distinctiveness of the value scorecard in relation to the balanced scorecards used by many academic libraries. The new scorecard is unbalanced and complex, offers insight and prediction (by correlating activity with outcomes), provides rich qualitative data to support story telling and advocacy, and its focus is the creation of value as defined by institutional values, rather than the delivery of vision represented by organizational strategy. These points are well made, though Town's (2015b, $p$. 239) earlier assertion that "The Balanced Scorecard may be weak in providing evidential proof beyond the library envelope" seems to conflate failings in library implementation with weaknesses in the framework; if library scorecards have failed to evidence their contributions to research, it suggests rather that libraries have either not prioritized such contributions in their visions and strategies, or not reflected their strategies accurately in their scorecards. He goes on to clarify that he is not suggesting libraries abandon existing practices based on the Balanced Scorecard, which can "be neatly folded in to the dimensions of the Value Scorecard", and also explains how the two approaches have been brought together at York in the design of a single data collection tool, based on an online form devised by the University of Wollongong though he also notes that some data sets are not sourced or managed via the template (such as university corporate data and professional association statistics).

Although the paper essentially describes empirical action research (and practical development), the section on the fourth dimension, (library) virtue includes some conceptual development, as Town (2015b, p. 247) explains "what is sought here is evidence of a virtuous circle in which excellence is rewarded by further investment and support to achieve successively higher levels of service" [emphasis added]. The term "virtue" is used to reflect and signal the transcendent contribution sought. 
"In times of pressure and financial constraint, some aspects of practical excellence might be traded off, but what cannot be lost in this context is the reputation gained by moral excellence. ... Measurement systems must therefore be geared back to library, institutional and societal values" (Town, 2015b, p. 247).

The message here is that evidence of service quality is not enough, but must be accompanied by evidence of both short and longer-term impact. Town (2015b) acknowledges that York needs to develop stronger evidence of impact, and cites work done at the University of Huddersfield (Stone and Ramsden, 2013) as a model for combining evidence of library engagement with student attainment data. The paper concludes with a useful summary of areas where more work is needed on implementing the scorecard at York, including data set combination for proof of impact, qualitative data mining for narrative evidence, measures for intangible asset evaluation, a full system for customer relationship management, and a dashboard for visual representation of the scorecard. However, overall, he concludes that implementing the value scorecard has already benefited his own library in terms of improved position in local and national rankings. Another significant benefit identified is that "the framework has served to provide an ontology for staff in thinking about measurement and assessment" (Town, 2015b, p. 248).

\section{CONCLUSION}

Stephen Town describes his work as characterized on the one hand by "Performativity, in the sense of improving organizational effectiveness through measurement" (Town, 2015a, p. 641; 2015 b, p. 248), which he describes as an expectation of his formal institutional role (Town, 2014b); and, on the other hand, by "advocacy of the library within and beyond the institution", particularly "strategic advocacy" and "advocacy to higher levels in the university (Town, 2015b, pp. $238,240,248)$. Both ideas are a constant presence, implicitly or explicitly, in his writing. Advocacy is a key theme of his work for SCONUL, stated as "the original motivation" for VAMP (Town, 2007, p. 444), and also recognized as an important benefit of LibQUAL+, at both national and local level (Killick and Town, 2012b; Town, 2016). His work is also distinguished by having a strong theoretical orientation, enabling him to contribute significantly to the theory of value measurement, while also being practice-based, and generating real, meaningful outcomes that have not only benefited his own institution, but also provided insights and inspiration for other libraries around the world, as a result of the international dissemination of his research.

Readers may be familiar with George A. Miller's (1956) "Law" about the magical number seven, presented in one of the most highly cited papers in psychology. Based on the present review, Town apparently subscribes to this popular theory: he gave us the Seven Pillars Model of Information Literacy, which he describes as the result of a "thought experiment" (Town, 2003b, p. 93), and not directly influenced by other seven-element models, such as Christine Bruce's (1997) Seven Faces of Information Literacy, although he does claim support for a sevenelement model as "the norm" from the Book of Proverbs (Town, 2000e, p. 16). Town (2014a, p. 331; 2015d, p. 243) also gave us a Seven Markets Model for academic libraries (which he modified from a six-market model in the marketing literature); and, along the way, he charmed international colleagues at the 2001 Performance Measurement Conference with an after-dinner speech proposing "Seven Toasts for a Summer Evening in Pittsburgh" (Town, 2002a).

However, there is also substantial evidence for Town's affiliation with a rival group led by Nelson Cowan (2001) supporting the number four. His contribution to the inaugural issue of PMM (updated from the 1997 Performance Measurement Conference) offered "Four hypotheses for a new framework" for academic library performance measurement (Town 2000c, p. 45), and a later similarly challenging contribution to the e-measures debate at the 2004 eVALUEd conference in Birmingham (associated with a Higher Education Funding Council for England 
Good Management Practice project on e-library evaluation) suggested "four potential routes for a better understanding of measurement dimensions" in the e-environment (Town, 2004a, p. 191). More significantly, his proposed value scorecard "comprises four areas or dimensions of value measurement" (Town and Kyrillidou, 2013, p. 11), which Town (2015b, p. 238) later linked to "four Is" reflecting demands of the current context - Impact proof, Innovation delivery, Infrastructure sustainability, and "Intimacy with markets and partners". Similarly, "The proposed framework for human capital evaluation is based on four dimensions" (Town, 2014b, p. 75).

On a more serious note, Town has given the community four distinct intellectual products, namely:

- an information literacy model, the Seven Pillars, which has been reviewed, updated, and independently judged to have "stood the test of time" and "attracted widespread recognition within the academic library community in the UK and internationally" (Goldstein, 2015, p. 8; SCONUL, 2011);

- a library benchmarking methodology, based on industry best practices adapted and field-tested in the library sector, and captured in the SCONUL Benchmarking Manual (Town, 2000d);

- a values-based scorecard framework for assessing and measuring library value, which offers a broader, higher-level view of library resources, services, and facilities; addresses longstanding weaknesses in library measurement practice; and incorporates tools with potential for stand-alone usage, notably the Seven Markets Model supporting the key area of relationship management (Town and Kyrillidou, 2013; Town, 2015b; Town 2015d);

- a quality maturity/capability tool, developed to support benchmarking activities, but with potential for application in other contexts, including meta-level measurement as part of the scorecard framework (Wilson and Town, 2006; Town, 2014b).

The quality of Town's work has been recognized by two Emerald Outstanding Paper Awards for development of the Quality Maturity Model and the Value Scorecard (Wilson and Town, 2006; Town and Kyrllidou, 2013). The quantity of his output is evident from the references cited here; in addition, a bibliometric analysis of contributions to the Proceedings of the five Library Assessment Conferences held from 2006 to 2014 ranked Town among the top four most prolific and as the second most productive of the authors listed (Dash, Sahoo and Mohanty, 2015).

Town has advanced practice in his own institutions and across the library and information sector through his leadership and coordination of initiatives, projects and programmes in the areas of service quality and performance improvement. He has also extended our conceptual understanding of the measurement and evaluation of library and information services, by introducing colleagues to concepts, theories and models from other disciplines; building on, but also adding to promising ideas and pioneering work of other thinkers and practitioners in the library and information arena. He has given new meanings to old terms, not just developing novel vocabulary, but creating a whole new "ontology of performance" for the library community, as well as "an ontology for staff in thinking about measurement and assessment" (Town, 2009a, p. $389 ; 2015$ b, p. 248). He has acknowledged the good work of others and been keen to engage colleagues in his quest for value, but has also critiqued weak thinking and challenged poor practice in the interests of advancing the field. To borrow a well-known epithet from our profession, he has been a true "Mover and Shaker" for the performance measurement world. 


\section{REFERENCES}

ACRL (2000), Information Literacy Competency Standards for Higher Education, Association of College \& Research Libraries, Chicago, available at http://www.ala.org/acrl/standards/informationliteracycompetency.

Anderson, R. (2015), "A quiet culture war in research libraries - and what it means for librarians, researchers and publishers", Insights, Vol. 28 No. 2, pp. 21-27, doi:10.1629/uksg.230, available at http://insights.uksg.org/articles/10.1629/uksg.230/

Armstrong, C., Boden, D., Town, S., Woolley, M., Webber, S. and Abell, A. (2005), "CILIP defines information literacy for the UK", Library + Information Update, Vol. 4 No. 1-2, pp. 2225.

Bell, S.J. and Shank, J. (2004), "The blended librarian: a blueprint for re-defining the teaching and learning role of academic librarians", College \& Research Libraries News, Vol. 65 No. 7 , pp. 372-375, available at http://crln.acrl.org/content/65/7/372.full.pdf.

Brophy, P. (2007), "Narrative based practice" [Commentary], Evidence Based Library and Information Practice, Vol. 2 No. 1, pp. 149-158, available at https://ejournals.library.ualberta.ca/index.php/EBLIP/article/view/137/248.

Brophy, P. (2008), "Telling the story", Performance Measurement and Metrics, Vol. 9 No. 1, pp. 7-17, doi:10.1108/14678040810869387.

Bruce, C. (1997), The Seven Faces of Information Literacy, Auslib Press, Adelaide.

Cameron, K.S., Quinn, R.E., DeGraff, J. and Thakor, A.V. (2006), Competing Values Leadership: Creating Value in Oganizations, Edward Elgar, Cheltenham; Northampton, MA.

Cowan, N. (2001), "The magical number 4 in short-term memory: a reconsideration of mental storage capacity", Behavioral and Brain Sciences, Vol. 24 No. 1, pp. 87-114, doi:10.1017/S0140525X01003922.

Dash, N.K., Sahoo, J. and Mohanty, B. (2015), "Evolution of library assessment literature - a bibliometric analysis of LAC Proceedings", 10th International CALIBER-2015, Shimla, India, March 12-14, 2015, INFLIBNET Centre, Gandhinagar, pp. 91-106, available at http://ir.inflibnet.ac.in/bitstream/1944/1848/1/9.pdf.

German, L. and Namachchivaya, B.S. (2013), Innovation and R\&D [SPEC kit 339], Association of Research Libraries, Washington, DC.

Goldstein, S. (2015), Perceptions of the SCONUL Seven Pillars of Information Literacy: A Brief Review, SCONUL, London, available at http://www.sconul.ac.uk/page/seven-pillars-ofinformation-literacy.

Gorman, M. (2002), "The value and values of libraries", Bodleian Library Record, Vol. 17, No. 6, pp. 449-463.

Jantz, R.C. (2012), "Innovation in academic libraries: an analysis of university librarians' perspectives", Library \& Information Science Research, Vol. 34 No. 1, pp. 3-12, doi:10.1016/j.lisr.2011.07.008.

Killick, S, and Town, S. (2012a), "LibQUAL+: the SCONUL experience", SCONUL Focus, No. 54, pp. 29-32, available at http://www.sconul.ac.uk/sites/default/files/documents/9 0.pdf.

Killick, S. and Town, S. (2012b), "LibQUAL+®: the UK and Irish experience", in Hall, I., Thornton, S. and Town, S. (Eds.), Proceedings of the 9th Northumbria International Conference on Performance Measurement in Libraries and Information Services: Proving Value in Challenging Times, August 22-26, 2011, University of York, York, pp. 201-204, available at http://www.york.ac.uk/about/departments/support-and-admin/informationservices/performance/northumbria-conference/9th-conference/proceedings/.

Kostagiolas, P.A. and Asonitis, S. (2009), "Intangible assets for academic libraries: definitions, categorization and an exploration of management issues", Library Management, Vol. 30 No. 6/7, pp. 419-429, doi:10.1108/01435120910982113. 
Kyrillidou, M., Cook, C., Heath, F., Hiller, S., Town, J.S. and Thompson, B. (2015), "A 15-year retrospective on LibQUAL+" [Panel Abstract], in Durso, S, Hiller, S., Kyrillidou, M. and Pappalardo, A. (Eds.), Proceedings of the 2014 Library Assessment Conference: Building Effective, Sustainable, Practical Assessment, August 4-6, 2014, Seattle, WA, Association of Research Libraries, Washington, DC, pp. 125-128, available at http://libraryassessment.org/bm doc/proceedings-lac-2014.pdf.

Lankes, R.D. (2008), "Virtual reference to participatory librarianship: expanding the conversation", Bulletin of the American Society for Information Science and Technology, Vol. 34 No. 2, pp. 11-14, available at https://www.asis.org/Bulletin/Dec-07/DecJan08_Lankes.pdf.

Lankes, R.D., Silverstein, J. and Nicholson, S. (2007), "Participatory networks: the library as conversation", Information Technology and Libraries, Vol. 26 No. 4, pp. 17-33, doi:10.6017/ital.v26i4.3267, available at http://ejournals.bc.edu/ojs/index.php/ital/article/view/3267/2880.

Lock, S.A. and Town, S. (2003)," LibQUAL+ in the UK: a brief report on the SCONUL pilot", SCONUL Newsletter, No. 29, pp. 8-10, available at http://web.archive.org/web/20040503184516/http://www.sconul.ac.uk/pubs_stats/newsletter/ 29/3.PDF.

Lock, S.A. and Town, S. (2005), "LibQUAL+ in the UK and Ireland: three years' findings and experience", SCONUL Focus, No. 35, pp. 41-44, available at https://dspace.lib.cranfield.ac.uk/bitstream/1826/8659/1/14.pdf.

Lock, S.A. and Town, S. (2007a), "LibQUAL+ in the local context: results, action and evaluation", Proceedings of the 6th Northumbria International Conference on Performance Measurement in Libraries and Information Services, Durham, 22-25 August 2005, Emerald, Bingley, pp. 219-225.

Lock, S.A. and Town, S. (2007b), "LibQUAL+ in the UK and Ireland: three years findings and experience", Proceedings of the 6th Northumbria International Conference on Performance Measurement in Libraries and Information Services, Durham, 22-25 August 2005, Emerald, Bingley.

Martindale, C. (1997), "SCONUL Benchmarking Study Group Seminar", SCONUL Newsletter, No. 12 , pp. 31-32.

Mathews, B. (2009), "Libraries \& the inspiration business", Library Journal, Vol. 134 No.11, p. 38.

Mathews, B. (2014), "Flip the model: strategies for creating and delivering value", Journal of Academic Librarianship, Vol. 40 No. 1, pp. 16-24, doi: 10.1016/j.acalib.2013.09.004.

Miller, G.A. (1956), "The magical number seven, plus or minus two: some limits on our capacity for processing information”, Psychological Review, Vol. 63 No. 2, pp. 81-97. doi:10.1037/0033-295X.101.2.343.

Molaro, A. and White, L.L. (Eds.) (2015), The Library Innovation Toolkit: Ideas, Strategies, and Programs. ALA Editions, Chicago.

Oakland, J.S. (1993), Total Quality Management: The Route to Improving Performance (2nd ed.), Butterworth-Heinemann, Oxford.

Pors, N.O. (2008), "Trust and organisational effectiveness: discrepancies between users' service preferences and the library system's construction of their needs", Performance Measurement and Metrics, Vol. 9 No. 1, pp. 59-68, doi:10.1108/14678040810869431.

Pors, N.O. and Johannsen, C.G. (2003), "Library directors under cross-pressure between new public management and value-based management", Library Management, Vol. 24 No. 1/2, pp. 51-60, doi:10.1108/01435120310454511.

Posner, M. (2013), "No half measures: overcoming common challenges to doing digital humanities in the library", Journal of Library Administration, Vol. 53 No. 1, pp. 43-52, doi:10.1080/01930826.2013.756694. 
RIN (2011), The Role of Research Supervisors in Information Literacy, Research Information Network, London, available at http://www.rin.ac.uk/system/files/attachments/Research_supervisors report for_screen.pdf. SCONUL (1999), Information Skills in Higher Education: A SCONUL Position Paper. Standing Conference of National and University Libraries, London, available at http://www.sconul.ac.uk/sites/default/files/documents/Seven pillars2.pdf.

SCONUL (2011), The SCONUL Seven Pillars of Information Literacy: Core Model For Higher Education, SCONUL Working Group on Information Literacy, London, available at http://www.sconul.ac.uk/sites/default/files/documents/coremodel.pdf.

Stone, G. and Ramsden, B. (2013), "Library impact data project: looking for the link between library usage and student attainment", College \& Research Libraries, Vol. 74 No. 6, pp. 546559, doi:10.5860/crl12-406, available at http://crl.acrl.org/content/74/6/546.full.pdf.

Town, S. (1995), "Benchmarking and performance measurement", in Wressell, P. (Ed.), Proceedings of the 1st Northumbria International Conference on Performance Measurement in Libraries and Information Services, Longhirst Hall, Northumberland, 31 August-4 September, 1995, Information North, Newcastle upon Tyne, pp. 83-88.

Town, S. (1996), "Benchmarking as an approach to quality", in Knowles, B. (Ed.), Routes to Quality: Proceedings of the Conference held at Bournemouth University, 29-31 August,1995, Bournemouth University Library \& Information Services, Bournemouth, pp. 71-79.

Town, S. (1998), "Performance or measurement? Proceedings of the 2nd Northumbria International Conference on Performance Measurement in Libraries and Information Services, Longhirst Hall, Northumberland, September 7-11, 1997, Information North, Newcastle upon Tyne, pp. 1-8.

Town, S. (2000a), "Benchmarking: strife, theft or communion?", Proceedings of the 3rd Northumbria International Conference on Performance Measurement in Libraries and Information Services, Longhirst Hall, Northumberland, 27-31 August, 1999, Information North, Newcastle upon Tyne, pp. 81-88.

Town, S. (2000b), "Benchmarking the learning infrastructure: library and information service case studies", in Jackson, N. and Lund, H. (Eds.), Benchmarking for Higher Education, Society for Research into Higher Education and Open University Press, Buckingham, pp. 151-164.

Town, S. (2000c), "Performance or measurement?", Performance Measurement and Metrics, Vol. 1 No. 1, pp. 43-54, doi:10.1108/EUM0000000007224.

Town, S. (Ed.). (2000d), SCONUL Benchmarking Manual, Standing Conference of National \& University Libraries, London.

Town, S. (2000e), "Wisdom or welfare? The seven pillars model", in Corrall, S. and Hathaway, H. (Eds.), Seven Pillars of Wisdom? Good Practice in Information Skills Development: Proceedings of a Conference held at the University of Warwick, 6-7 July 2000, SCONUL, London, pp. 11-21.

Town, S. (2001), "Performance measurement of information skills education: What's important? Report and findings of a workshop held at the SCONUL Conference, Glasgow, April, 2001", SCONUL Newsletter, No. 22, pp. 21-24.

Town, S. (2002a), "Seven toasts for a summer evening in Pittsburgh" [After-Dinner Speech], in Stein, J., Kyrillidou, M. and Davis, D. (Eds.), Proceedings of the 4th Northumbria International Conference on Performance Measurement in Library and Information Services: Meaningful Measures for Emerging Realities, Pittsburgh, PA, 12-16 August 2001, Association of Research Libraries, Washington, DC, pp. 357-359, available at http://www.libqual.org/documents/admin/4np_secure.pdf. 
Town, S. (2002b), "Welfare or wisdom? Performance measurement of information skills education", in Stein, J., Kyrillidou, M. and Davis, D. (Eds.), Proceedings of the 4th Northumbria International Conference on Performance Measurement in Library and Information Services: Meaningful Measures for Emerging Realities, Pittsburgh, PA, 12-16 August 2001, Association of Research Libraries, Washington, DC, pp. 203-208, available at http://www.libqual.org/documents/admin/4np_secure.pdf.

Town, S. (2003a), "Information literacy: definition, measurement, impact", in Martin, A. and Rader, H. (Eds.), Information literacy and IT: Enabling Learning in the 21st Century, Facet, London, pp. 53-65.

Town, S. (2003b), "Information literacy and the information society", in Hornby, S. and Clarke, Z. (Eds.), Challenge and Change in the Information Society, Facet, London, pp. 83-103.

Town, S. (2004a), "E-measures: a comprehensive waste of time?", Vine, Vol 34 No. 4, pp. 190195. doi:10.1108/03055720410570984.

Town, S. (2004b), "Filling the void or bridging the deep? LibQUAL+ in the UK", Proceedings of the 5th Northumbria International Conference on Performance Measurement in Library and Information Services: Library measures to fill the void: Assessing the outcomes, 28-31 July 2003, Collingwood College, Durham, Emerald, Bingley, pp. 212-219.

Town, S, (2006), "The SCONUL value and impact measurement programme (VAMP): a progress report", SCONUL Focus, No. 38, pp. 114-116, available at https://web.archive.org/web/20071029011101/https://www.sconul.ac.uk/publications/newslett er/38/33.pdf.

Town, S. (2007), "Value and impact measurement: a UK perspective and progress report on a national programme (VAMP)", in DeFranco, F., Hiller, S., Hinchliffe, L.J., Justh, K., Kyrillidou, M., Self J. and Stein, J. (Eds.), Proceedings of the 2006 Library Assessment Conference: Building Effective, Sustainable, Practical Assessment, September 25-27, 2006, Charlottesville, VA, Association of Research Libraries, Washington, DC, pp. 437-447, available at http://libraryassessment.org/bm doc/proceedings-lac-2006.pdf.

Town, S. (2009a), "Building a resource for practical assessment: adding value to value and impact”, in Hiller, S., Justh, K., Kyrillidou, M. and Self, J. (Eds.), Proceedings of the 2008 Library Assessment Conference: Building Effective, Sustainable, Practical Assessment, August 4-7, 2008, Seattle, WA, Association of Research Libraries, Washington, DC, pp. 387392, available at http://libraryassessment.org/bm doc/proceedings-lac-2008.pdf.

Town, S. (2009b), "Reaction to keynote panel: the most important challenge for library assessment", in Hiller, S., Justh, K., Kyrillidou, M. and Self, J. (Eds.), Proceedings of the 2008 Library Assessment Conference: Building Effective, Sustainable, Practical Assessment, August 4-7, 2008, Seattle, WA, Association of Research Libraries, Washington, DC, pp. 2123, available at http://libraryassessment.org/bm doc/proceedings-lac-2008.pdf.

Town, S. (2011a), "From values to value measurement: a metaphysical enquiry", in Graham, M.E. and Thornton, S. (Eds.), Proceedings of the 8th Northumbria International Conference on Performance Measurement in Libraries and Information Services: Libraries Plus: Adding Value in the Cultural Community: 17-20 August 2009, Istituto degli Innocenti, Florence. Northumbria University Press, Newcastle upon Tyne.

Town, S. (2011b), "The value of libraries: the relationship between change, evaluation and role", in Baker, D. and Evans, W. (Eds.), Libraries and Society: Role, Responsibility and Future in an Age of Change, Chandos, Oxford, pp. 303-325.

Town, S. (2011c), "Value, impact, and the transcendent library: progress and pressures in performance measurement and evaluation", in Hiller, S., Justh, K, Kyrillidou, M. and Self, J. (Eds.), Proceedings of the 2010 Library Assessment Conference: Building Effective, Sustainable, Practical Assessment, October 24-27, 2010, Baltimore, MD, Association of Research Libraries, Washington, DC, pp. 267-276, available at http://libraryassessment.org/bm doc/proceedings-lac-2010.pdf. 
Town, S. (2011d), "Value, impact, and the transcendent library: progress and pressures in performance measurement and evaluation", Library Quarterly, Vol. 81 No. 1, pp. 111-125, doi:10.1086/657445.

Town, S. (2014a), "Measures of relationship capital for the value scorecard", in Hall, I., Thornton, S. and Town, S. (Eds.), Proceedings of the 10th Northumbria International Conference on Performance Measurement in Libraries and Information Services, July 22-25, 2013, University of York, York, pp. 325-333, available at http://www.york.ac.uk/about/departments/support-and-admin/informationservices/performance/northumbria-conference/10th-conference/proceedings/.

Town, S. (2014b), "The value of people: a review and framework for human capital assessment in academic and research libraries", Performance Measurement and Metrics, Vol. 15 No. 1/2) pp. 67-80, doi:10.1108/PMM-05-2014-0019.

Town, S. (2015a), "Evidence based organizational change: people surveys, strategies and structures", Library Management, Vol. 36 No. 8/9, pp. 623-643, doi:10.1108/LM-09-20150060.

Town, S. (2015b), "Implementing the value scorecard", Performance Measurement and Metrics, Vol. 16 No. 3, pp. 234-251, doi:10.1108/PMM-10-2015-0033.

Town, S. (2015c), "Making value measurement a reality: implementing the value scorecard" [Presentation abstract], in Durso, S., Hiller, S., Kyrillidou, M. and Pappalardo, A. (Eds.), Proceedings of the 2014 Library Assessment Conference: Building Effective, Sustainable, Practical Assessment, August 4-6, 2014, Seattle, WA, Association of Research Libraries, Washington, p. 721, available at http://libraryassessment.org/bm doc/proceedings-lac2014.pdf.

Town, S. (2015d), "Measures of relationship capital for the value scorecard", Library Management, Vol. 36 No. 3, pp. 235-247, doi:10.1108/LM-11-2014-0134.

Town, S. (2016), "LibQUAL+: a quality survey case study", in Atkinson, J. (Ed.), Quality and the Academic Library: Reviewing, Assessing and Enhancing Service Provision, Chandos, Cambridge, MA; Kidlington, pp. 209-220, doi:10.1016/B978-0-12-8-2105-7.00028-2.

Town, S., and Kyrillidou, M. (2012), "Developing a value scorecard", in Hall, I., Thornton, S. and Town, S. (Eds.), Proceedings of the 9th Northumbria International Conference on Performance Measurement in Libraries and Information Services: Proving Value in Challenging Times, August 22-26, 2011, University of York, York, pp. 415-422, available at http://www.york.ac.uk/about/departments/support-and-admin/informationservices/performance/northumbria-conference/9th-conference/proceedings/.

Town, S., \& Kyrillidou, M. (2013), "Developing a values scorecard", Performance Measurement and Metrics, Vol. 14 No. 1, pp.7-16, doi:10.1108/14678041311316095.

Town, S., Black, J., Hall, I., \& Smith, K. (2013), "The value of our people: towards a scorecard for human capital in academic and research libraries", in Hiller, S., Kyrillidou, M., Pappalardo, A., Self, J. and Yeager, A. (Eds.), Proceedings of the 2012 Library Assessment Conference: Building Effective, Sustainable, Practical Assessment, October 29-31, 2012, Charlottesville, $V A$, Association of Research Libraries, Washington, DC, pp. 51-60, available at http://libraryassessment.org/bm doc/proceedings-lac-2012.pdf.

White, L.N. (2007), "An old tool with potential new uses: return on investment", The Bottom Line, Vol. 20 No. 1, pp. 5-9, doi:10.1108/08880450710747407.

Wilson, F. and Town, J.S. (2006), "Benchmarking and library quality maturity", Performance Measurement and Metrics, Vol. 7 No. 2, pp. 75-82, doi:10.1108/14678040610679461.

Wilson, F. and Town, J.S. (2007), "Benchmarking and library quality maturity", Proceedings of the 6th Northumbria International Conference on Performance Measurement in Libraries and Information Services, Durham, 22-25 August 2005, Emerald, Bingley, pp. 401-406. 


\section{ABOUT THE AUTHOR}

Sheila Corrall is a Professor in the Department of Information Culture \& Data Stewardship at the University of Pittsburgh, where she teaches courses on research methods and academic libraries, and a seminar on academic culture and practice. Her research interests include the application of business management concepts to library and information services, collection development in the digital world, and the evolving roles of library and information professionals. She moved to the USA from the University of Sheffield, where she was head of the iSchool for four years. She was previously director of library and information services at three UK universities. Sheila Corrall can be contacted at: scorrall@pitt.edu. 